\title{
Immunolocalization of cholesterol side-chain-cleavage cytochrome $P-450$ and ultrastructural studies of bovine corpora lutea
}

\author{
R. J. Rodgers*, H. F. Rodgers $\dagger$, M. R. Waterman $\dagger$ and E. R. Simpson* $† \ddagger$ \\ *Cecil H. and Ida Green Center for Reproductive Biology Sciences, Departments of \\ $\dagger$ Biochemistry and $\ddagger$ Obstetrics and Gynecology, University of Texas Health Science Center, \\ 5323 Harry Hines Boulevard, Dallas, Texas 75235, U.S.A.
}

\begin{abstract}
Summary. Corpora lutea were collected from cows at four stages of the luteal phase and prepared for immunostaining at the light microscope level. Other corpora lutea, which were fully developed, were dispersed by collagenase treatment and freshly isolated and cultured cells were processed for immunostaining. Electron microscopy was carried out on mature corpora lutea and freshly isolated cells. Positive staining for cholesterol side-chain-cleavage cytochrome P-450 (P-450 $\left.{ }_{\text {scc }}\right)$, an inner-mitochondrial membrane enzyme considered to catalyse the rate-limiting step in the conversion of cholesterol to progesterone, was observed in all corpora lutea. The intensity of staining was much greater in mature corpora lutea than in young or regressing corpora lutea. Only small and large luteal cells stained positively and cells of the vasculature and other connective tissue elements did not. When cells were cultured and had become flatter, the intensity of immunostaining was observed to be greater in large luteal cells than in small luteal cells which was interpreted to be due, in part, to the greater volume density of mitochondria in these cells. In some cultured small luteal cells the pattern of immunostaining appeared as whorls of strands encircling the nucleus. This pattern was interpreted as a three-dimensional network of mitochondria organized into 'strands', more than one mitochondrion in cross-section, perhaps formed during the process of attachment and elongation of the cells. Further observations made at the electron microscope level, included the presence of close $(5-8 \mathrm{~nm})$ contacts with interconnecting septa between small luteal cells in tissue.
\end{abstract}

\section{Introduction}

The bovine corpus luteum has two types of luteal cells, small and large; which have been distinguished from each other on the basis of their size and morphology (Priedkalns \& Weber, 1968a, b; Parry et al., 1980; Archbald et al., 1981; Chegini et al., 1984; Fields et al., 1985), and in-vitro functions (Ursely \& Leymarie, 1979a,b; Koos \& Hansel, 1981). It would appear that a substantial proportion of small luteal cells and large luteal cells are derived respectively from the theca and granulosa cells of the ovulating follicle (Donaldson \& Hansel, 1965; Alila \& Hansel, 1984), but it has also been suggested that theca-derived small luteal cells may give rise to large luteal cells during the life-span of the corpus luteum (Alila \& Hansel, 1984). From recent data it would appear that the small and large luteal cells of the cow are steroidogenic, based on their ability to produce progesterone in vitro (Ursely \& Leymarie, 1979a,b; Koos \& Hansel, 1981). However, in these in-vitro studies it was not possible to determine whether all cells in each culture contributed equally to the total amount of steroid synthesized, and problems associated with impure cell fractions, due in one case to clumps of small luteal cells contaminating fractions of large luteal cells (Koos \& Hansel, 
1981), hinder the precise interpretation of data. Moreover, it was possible that the behaviour of cells changed when they were transferred into an in-vitro situation. Therefore another approach to the study of the steroidogenic functions of small and large luteal cells would be of value.

The rate-limiting step in the synthesis of steroid hormones from cholesterol is considered to be the cholesterol side-chain-cleavage (scc) reaction catalysed by cytochrome $\mathbf{P}-450_{\text {scc }}$ of the innermitochondrial membrane. Changes in the specific and total tissue content of cytochrome $\mathrm{P}-450_{\mathrm{scc}}$ in bovine corpora lutea during the oestrous cycle parallel the changes observed in the peripheral plasma concentrations of progesterone (Rodgers et al., 1986a), suggesting that the amount of progesterone produced is related to the amount of luteal cytochrome $\mathrm{P}-450_{\mathrm{scc}}$. Another approach to understanding the function of small and large luteal cells would be to immunolocalize cytochrome $\mathrm{P}-450_{\mathrm{scc}}$. In the present study cytochrome $\mathrm{P}-450_{\text {scc }}$ has been immunolocalized in bovine corpora lutea at various stages of their development and these results have been related to the ultrastructure of small and large luteal cells.

\section{Materials and Methods}

Tissues. Ovaries from non-pregnant cows were collected at a local abattoir within 20 min of slaughter. Corpora lutea were classified into four stages of the luteal phase, I to IV, on the basis of their gross morphological appearance using the method of Ireland et al. (1980). This procedure has been validated in a blind trial (Ireland et al., 1980), and by histological assessment of the classified corpora lutea (Rodgers et al., 1986a). Corpora lutea of Stage I included recently ovulated follicles and developing corpora lutea. Stages II and III corresponded to early-mid- and late-mid-luteal phases of the oestrous cycle respectively. Corpora lutea from these stages were mature, whereas corpora lutea from Stage IV were degenerate.

Tissue dissociation and culture. Ovaries were collected into ice-cold Hank's balanced salt solution (Irvine Scientific, Santa Ana, CA, U.S.A.) and transferred to the laboratory. Ovaries were dissected free of adhering tissue and were dipped in ethanol and then rinsed in sterile Dulbecco's modified Eagle's medium (DMEM) containing antibiotics (100 units penicillin/ml, $100 \mu \mathrm{g}$ streptomycin $/ \mathrm{ml}, 1.8 \mu \mathrm{g}$ fungizone $/ \mathrm{ml}, 100 \mu \mathrm{g} \mathrm{kanamycin} / \mathrm{ml}$ and $10 \mu \mathrm{g}$ gentamycin $/ \mathrm{ml}$ ). Tissues were subsequently handled in a sterile manner. Mature functional corpora lutea at Stages II and III were dissected from the ovaries and sliced with a Stadie-Riggs hand microtome. The slices of tissue were dissociated by incubating them with collagenase $(400 \mathrm{u} / \mathrm{ml} ; 10 \mathrm{ml} / \mathrm{g}$ tissue; Worthington Biochemical Company, Freehold, NJ, U.S.A.) at $37^{\circ} \mathrm{C}$. After $40 \mathrm{~min}$ the supernatant was discarded and the same volume of fresh collagenase was added. After a further $2 \mathrm{~h}$ incubation the tissue fragments were further dispersed by pipetting and then filtered through sterile cloth (square holes, $150 \mu \mathrm{m})$. The isolated cells were washed four times, resuspended in DMEM (10 ml/g original tissue) and cultured in DMEM containing $10 \%$ fetal calf serum $(1 \mathrm{ml}$ per well $)$ at $37^{\circ} \mathrm{C}$ in a humidified atmosphere of $5 \% \mathrm{CO}_{2}$ in air. Viability as judged by trypan blue staining was greater than $90 \%$.

Immunostaining. Six corpora lutea (Stages II and III) were dispersed by collagenase treatment and cytocentrifuge preparations were made of the cells. Cells were cultured on glass coverslips, rinsed in DMEM, and cultured and cytocentrifuged cells were stored at $-20^{\circ} \mathrm{C}$ until the day of immunostaining after fixation in $4 \%$ formalin. Cytocentrifuged and cultured cells were also stained with 'Diff-Quik' stain (Harlecko, NJ, U.S.A.) for general light microscopic examinations.

Nine corpora lutea of the cycle (Stages I to IV) were sliced and smaller segments of each were embedded in O.C.T. compound (Miles Scientific, Naperville, IL, U.S.A.) and frozen on solid $\mathrm{CO}_{2}$. Tissues were stored at $-70^{\circ} \mathrm{C}$ until the day of immunostaining. Frozen sections, each half a crosssection of a corpus luteum, were cut on a cryostat and then allowed to air-dry on a glass slide at room temperature for $5 \mathrm{~min}$. Sections for general histological examination were cut from each block, fixed in $5 \%$ formalin in phosphate-buffered $(0 \cdot 1 \mathrm{M}, \mathrm{pH} 7 \cdot 4)$ saline, and subsequently stained with haematoxylin and eosin. 
Cytocentrifuged cells, incubated cells and tissue sections were prepared for immunostaining as described by Rodgers et al. (1986b).

Antibodies. Cytochrome P-450 scc $_{\text {was }}$ warified from bovine adrenal cortex (Seybert et al., 1979) and kindly donated by Dr J. D. Lambeth (Emory University, Atlanta, GA, U.S.A.) and an IgG fraction, raised against cytochrome $\mathrm{P}-450_{\text {scc }}$ in rabbits, was prepared as described previously (DuBois et al., 1981). It has been shown previously by Western immunoblot analysis that this IgG reacts specifically with cytochrome $\mathrm{P}-450_{\mathrm{scc}}$ and does not cross-react to any significant degree with other proteins of bovine corpora lutea (Rodgers et al., 1986a).

Electron microscopy. Electron microscopy was carried out on luteal tissue from 6 corpora lutea (Stages II and III) and on freshly dispersed cells from 5 corpora lutea other than those used for immunostaining. The methods were similar to those used by Rodgers et al. (1986b) except that 4 tissues were additionally fixed en bloc in $0.58 \%$ uranylacetate for $30 \mathrm{~min}$.

\section{Results}

\section{Electron microscopy}

Tissue. An electron micrograph showing the major cell types in the corpus luteum of the cow is shown in Fig. 1. These include large luteal cells, small luteal cells, vasculature and other connective tissue cells. Descriptions have previously been given of bovine large and small luteal cells (Priedkalns \& Weber, 1968a; Fields et al., 1985). Therefore in this section only the salient features of these two cell types and additional observations will be described.

The large luteal cells had a high cytoplasmic density of mitochondria, the cristae of which have been described as being both lamellar and tubular. In this study, however, a substantial portion were tubular. The endoplasmic reticulum was extensive and predominantly smooth. However, rough endoplasmic reticulum could be found in a very small proportion of large luteal cells (e.g. Fig. 4). Secretory granules were present and exocytosis appeared to be localized to select areas of the cell membrane where folding of the membrane was more pronounced.

The small luteal cells were more numerous than the large luteal cells and their cytoplasm had a lower volume density of mitochondria than large luteal cells. The cristae of the mitochondria were mostly tubular but some appeared to be lamellar. The endoplasmic reticulum was comprised of both smooth and rough elements. The smooth endoplasmic reticulum was tubular and anastomosing and in some areas it was arranged in extensive whorls or arrays. The rough endoplasmic reticulum appeared to be randomly distributed throughout the cytoplasm and occurred either as single cisternae or as aggregates of parallel cisternae. The Golgi and associated vesicles, predominantly coated, was extensive. Lipid droplets were present in small luteal cells. Some cells appeared to have no lipid droplets, while others appeared to be filled with lipid droplets or have lipid droplets restricted to one area of the cytoplasm. A few granules, which looked similar to mature secretory granules of large luteal cells, were observed in the cytoplasm but exocytosis was not observed. The plasma membrane of small luteal cells was folded in some areas but in other areas small cells abutted closely to other small luteal cells in lengths of a few micrometres (Figs 1-3). At the ends of these areas of abutment, where the membranes became further separated apart, small clusters of filaments of adherens-type junctions were observed (Fig. 2). In these areas the gap between the two opposing membranes was of the order of 5-8 nm, larger than that of gap junctions ( $2 \mathrm{~nm}$; see Gilula, 1978) but of the same order as that reported for septate junctions of invertebrates (15-20 nm: Wood, 1959) and vertebrates (11-18 nm: Gobel, 1971; 21-30 nm: Friend \& Gilula, 1972). In some sections small septa spaced at regular intervals were observed to connect the two opposing membranes (Fig. 3). These septa appeared as narrow cylindrical structures similar to those observed in septate junctions of rat adrenal cortex (Friend \& Gilula, 1972). These areas of 

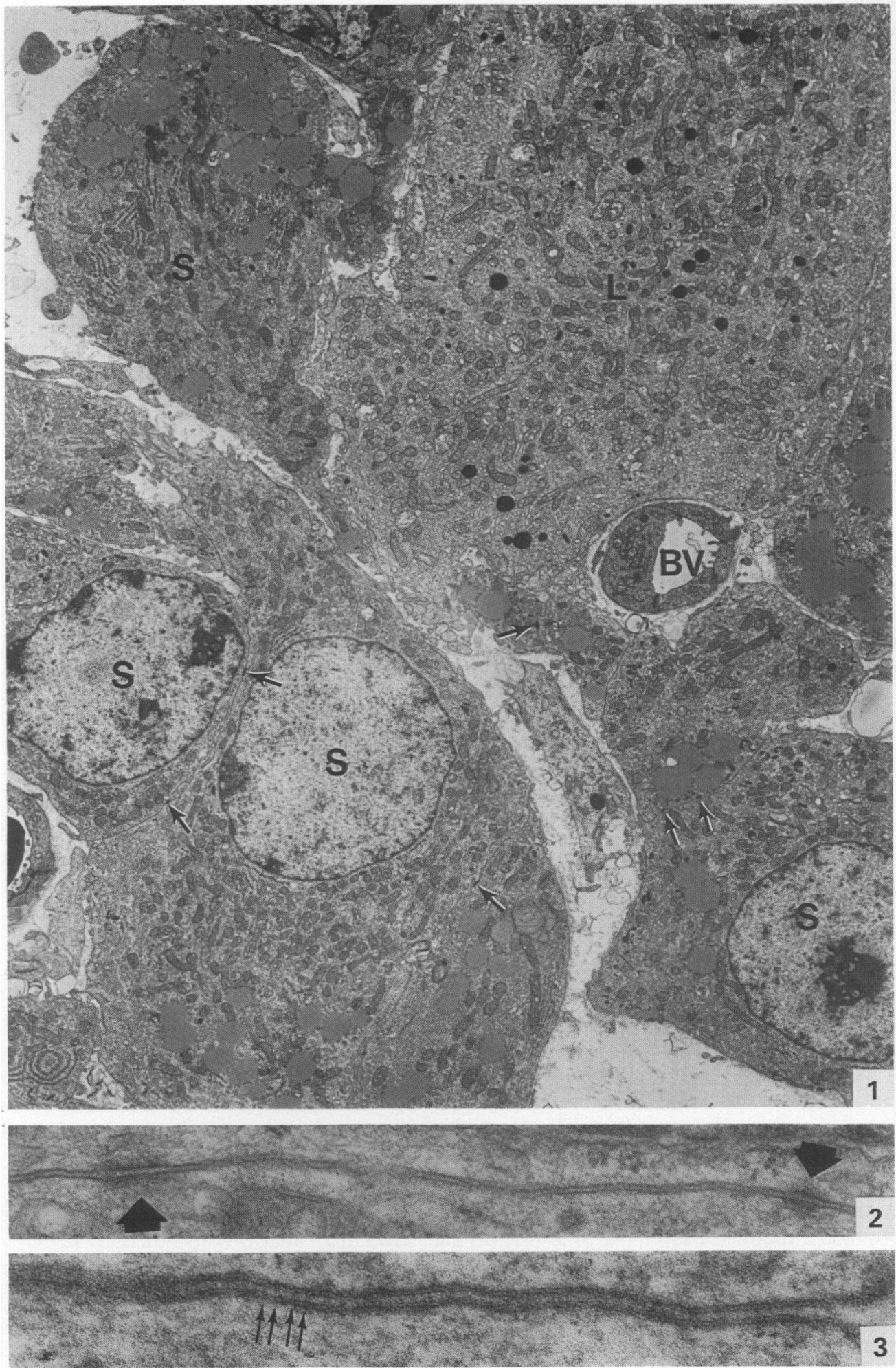
close abutment with associated adherens-type junctions were extensive and common between small luteal cells but were not observed between large luteal cells or between small and large luteal cells.

Dispersed cells. Based upon electron microscopic observations of the morphology of dispersed cells and the relative frequencies of each cell type it was possible to classify the cells at the light microscope level with a reasonable degree of certainty. In freshly prepared preparations of dispersed cells, large luteal cells were usually solitary. The limit of cell diameter that distinguished large from small luteal cells was considered to be $26 \mu \mathrm{m}$, a value greater than that of $18 \mu \mathrm{m}$ used by Chegini et al. (1984) and which by our observations would have classified a proportion of small luteal cells as large. Small luteal cells were $<26 \mu \mathrm{m}$ but $>13 \mu \mathrm{m}$ in diameter and were often in clumps, usually of 3 small luteal cells. The clumps appear to be the result of incomplete tissue dispersion and not merely formed by a loose association of solitary cells. Cells with a diameter of $<13 \mu \mathrm{m}$ were usually present in tight clumps, the numbers in which varied considerably. These cells were identified as endothelial cells and occasionally erythrocytes were observed trapped within the clumps.

At the electron microscope level, endothelial cells (Fig. 6), small luteal cells and large luteal cells were easily recognizable. Much of the morphological features of isolated large luteal cells (Fig. 4) were similar to those of cells in situ. Isolated small luteal cells (Fig. 5) also had similar morphology to those in situ. Some areas of the cell membranes were folded and it has been suggested that some surface folds of one cell interdigitate with folds of a neighbouring cell, thus retaining the small luteal cells in clumps (Koos \& Hansel, 1981). In other species (Rodgers \& O'Shea, 1982), and even in bovine large luteal cells in which the cell membrane is extensively folded, the cells do not remain in clumps after tissue dispersion. It is possible that the remnants of the areas of close abutment and associated adherens-type junctions between small luteal cells are responsible for this phenomenon. These areas could easily be recognized in dispersed cell preparations, although they appeared to be slightly disrupted and no septa were observed.

\section{Immunostaining}

Cow luteal tissues immunostained with anti-cytochrome $\mathrm{P}-450_{\mathrm{scc}} \mathrm{IgG}$ are shown in Figs 7-9. In immature corpora lutea (Stage I), staining was present in a proportion of cells which were scattered throughout the tissue (Fig. 7). Staining was localized to the cytoplasm and was of relatively low intensity. In mature corpora lutea (Stages II and III) staining was much more intense and was punctate, indicative of mitochondrial staining. It was localized to the cytoplasm of cells which were considerably larger than those seen in Stage I corpora lutea. Judging from the pattern of staining (Fig. 8) it appeared that both small and large luteal cells were stained positively and that capillaries, large blood vessels and connective tissue were not. In regressing corpora lutea (Stage IV) in which cytoplasmic vacuoles were visible, the majority of cells did not stain positively (Fig. 9). However, a few cells, much smaller than those of Stages II or III, did stain positively and the staining was punctate and cytoplasmic. No tissues stained positively when incubated with nonimmune IgG (Fig. 10).

Fig. 1. Electron micrograph of a fully-developed cyclic bovine corpus luteum showing small (S) and large (L) luteal cells and blood vessels (BV). Small adherens-type junctions (arrows) associated with septate-like junctions or contacts between small luteal cells are common. $\times 4000$.

Figs $2 \&$ 3. Electron micrographs of bovine luteal tissue showing an area of close abutment between the cell membranes of two small luteal cells. Two adherens-type junctions, often associated with these areas, are indicated (arrows) in Fig. $2(\times 60000)$ and some of the cylindrical septa between the two membranes in Fig. $3(\times 195000)$. 


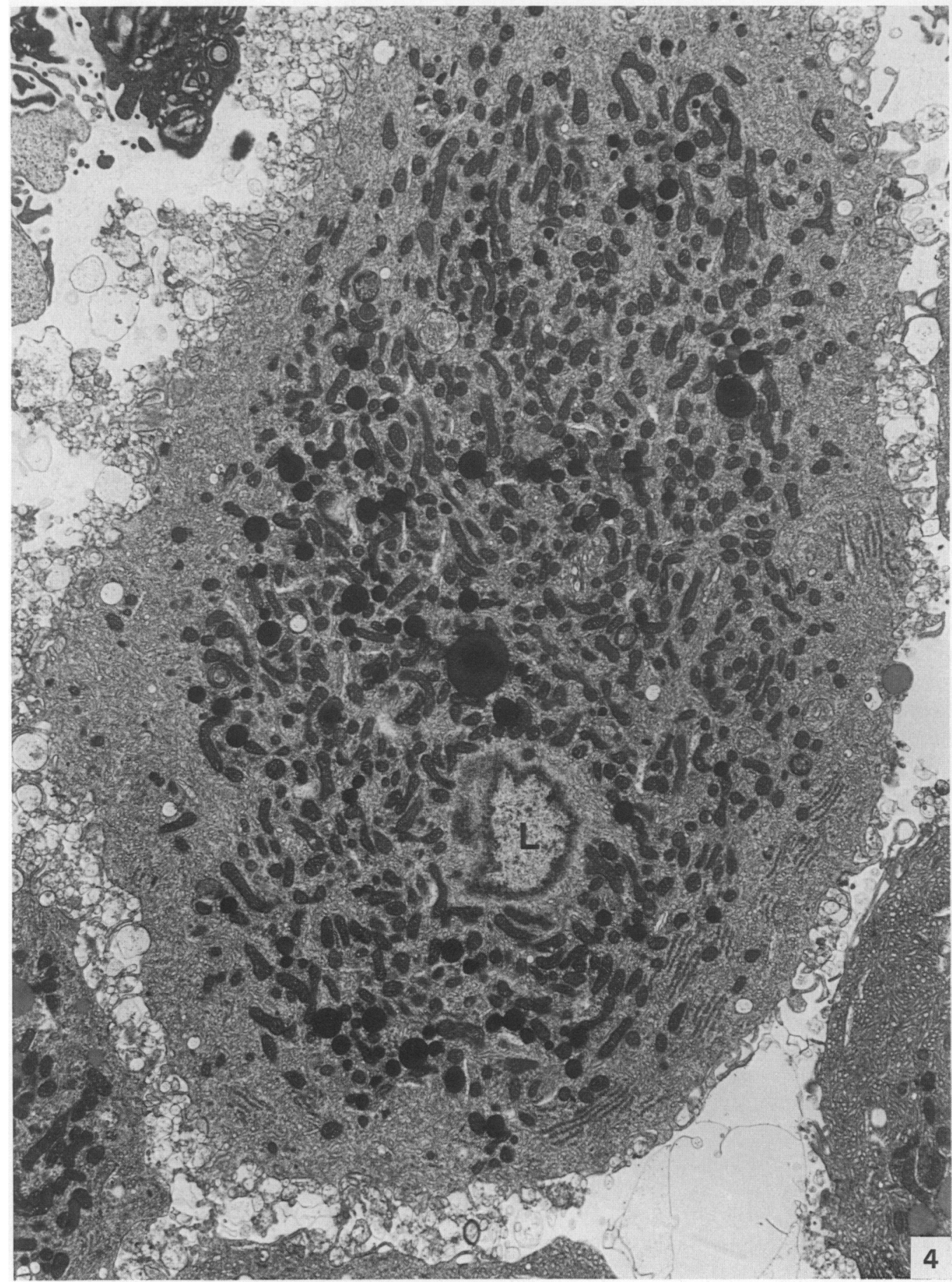

Fig. 4. Electron micrograph of an isolated large (L) luteal cell with a high volume density of mitochondria and smooth endoplasmic reticulum. Mitochondria are relatively absent from the periphery of the cell, and rough endoplasmic reticulum, although not common in large luteal cells, is present in this cell. $\times 5300$.

Fig. 5. An electron micrograph of an isolated small (S) luteal cells with relatively high volume densities of mitochondria and endoplasmic reticulum. Lipid droplets are present and these cells appear to be held in a loose association. Two endothelial (E) cells can also be seen. $\times 4500$. 

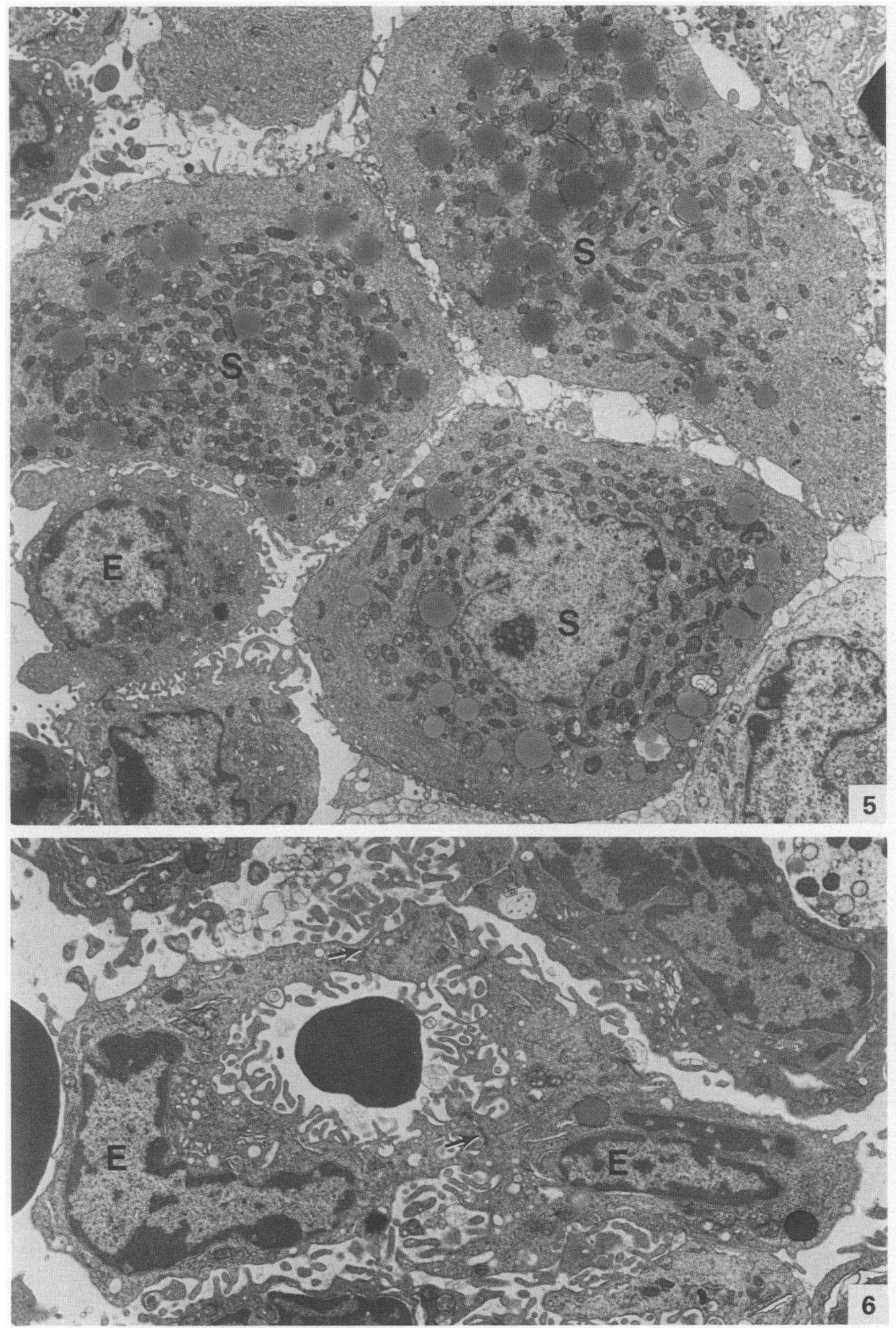

Fig. 6. An electron micrograph of isolated endothelial (E) cells still in a loose blood-vessel formation. Adherens-type junctions which hold these cells together are present (arrows). $\times 4400$. 

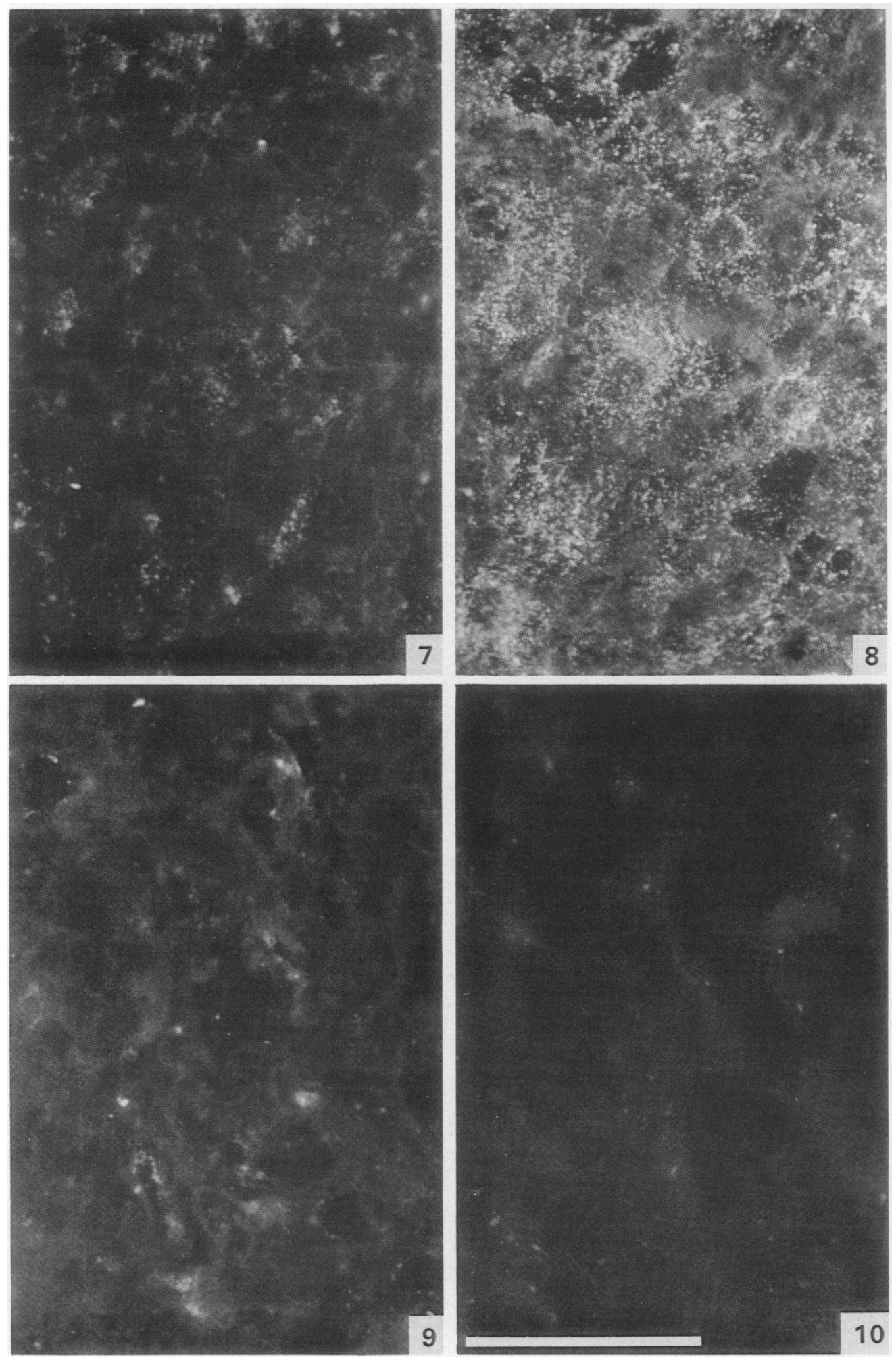

Figs 7-10. Light micrographs of immunofluorescent staining of CL from cows of Stages I (Fig. 7), 111 (Figs 8 \& 10) and IV (Fig. 9). In Figs 7-9 anti-cytochrome P-450 $0_{\text {sco }}$ IgG was used and in Fig. 10 non-immune $\mathrm{IgG}$ was used. Bar $=50 \mu \mathrm{m}$. 


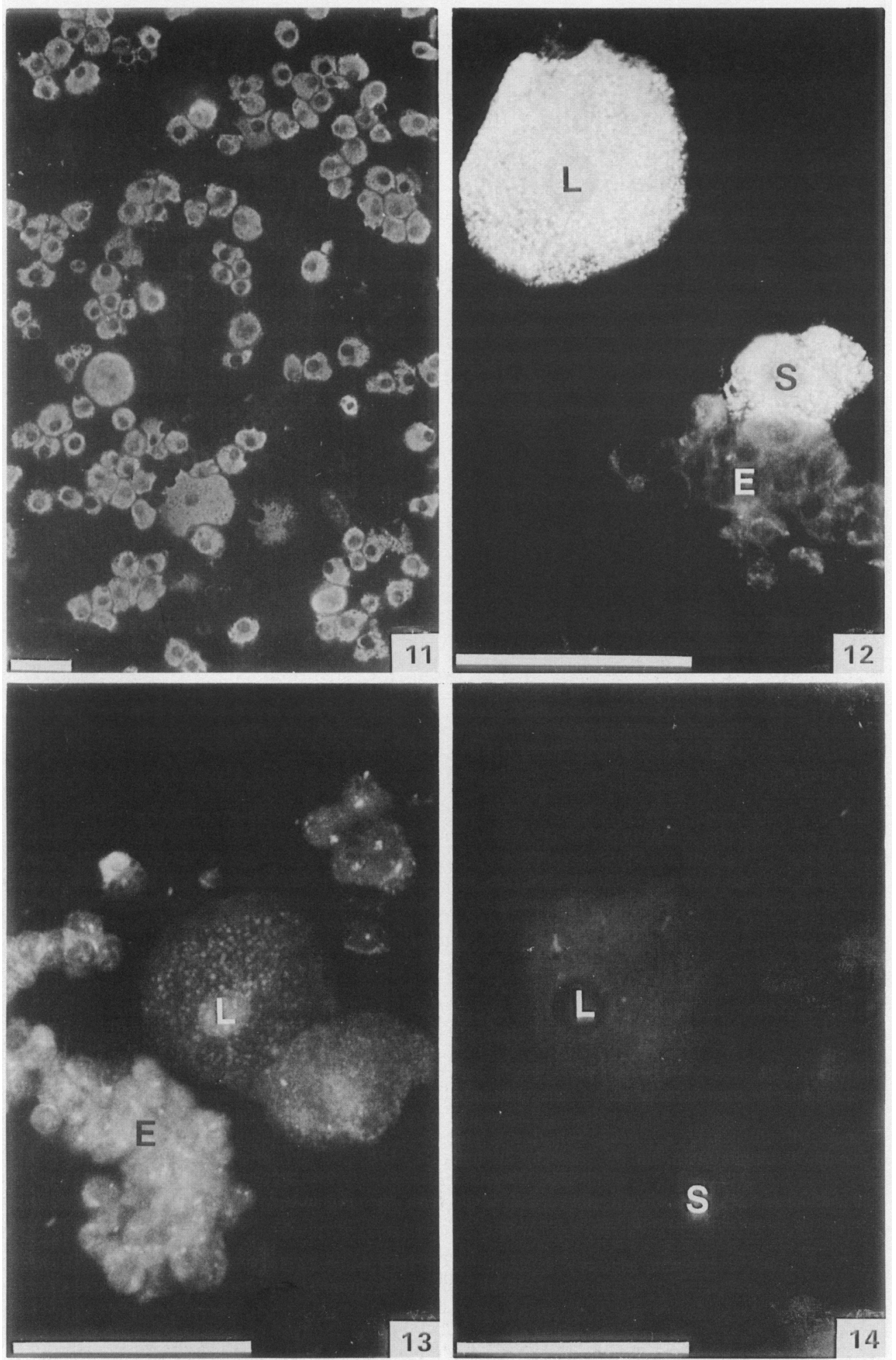

Figs 11-14. Light micrographs of immunofluorescent staining of isolated small (S) luteal cells, large (L) luteal cells and endothelial (E) cells of bovine corpora lutea. The primary IgG used

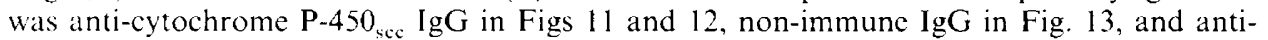
cytochrome P-450 $0_{\mathrm{scc}}$ IgG in the presence of purified cytochrome P-450 ${ }_{\mathrm{scc}}$ in Fig. 14. Only positive staining for cytochrome $\mathrm{P}-450_{\mathrm{scc}}$ was observed in the small and large luteal cells. Bars $=50 \mu \mathrm{m}$. 

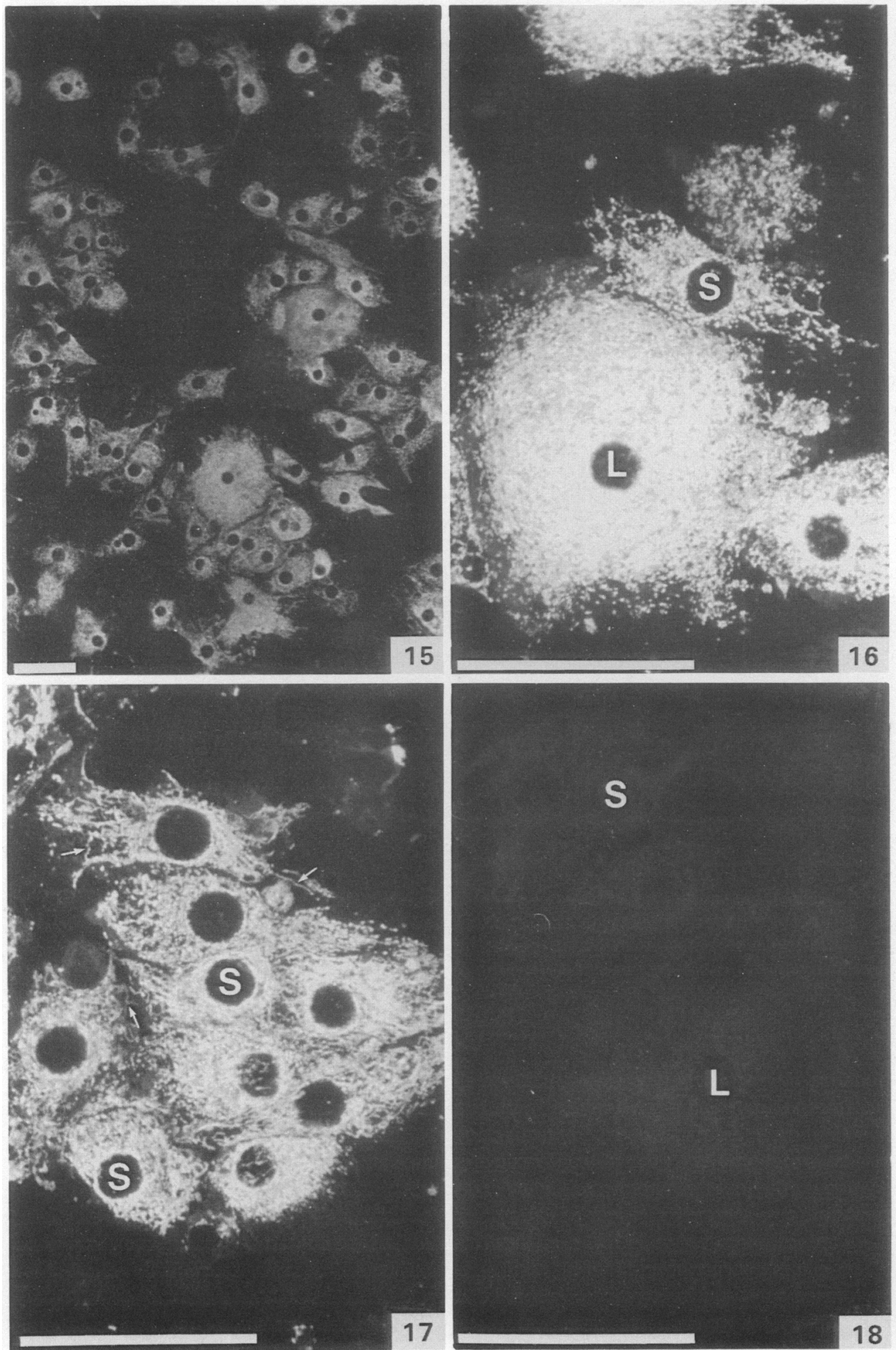
Immunostaining of freshly dispersed, cytocentrifuged cells from mature corpora lutea is shown in Figs 11-14. Small and large luteal cells stained positively for cytochrome P-450 ${ }_{\text {scc }}$ but endothelial cells did not (Figs $11 \& 12$ ). The staining was cytoplasmic and appeared granular. No cells stained positively with non-immune IgG (Fig. 13) or with anti-cytochrome P-450 ${ }_{\text {scc }}$ IgG in the presence of excess purified cytochrome $\mathrm{P}-450_{\text {scc }}$ (Fig. 14), suggesting that the positive staining observed with anti-cytochrome $\mathrm{P}-450_{\text {scc }} \mathrm{IgG}$ was specific for cytochrome $\mathrm{P}-450_{\text {scc }}$.

Immunostaining of cells isolated from mature corpora lutea and cultured for $24 \mathrm{~h}$ is shown in Figs 15-18. During culture, small and large luteal cells became flatter on the dish. The small luteal cells took on a more angular appearance while the large luteal cells retained a circular outline. Both small and large luteal cells stained positively for cytochrome P-450 ${ }_{\mathrm{scc}}$ and the staining was cytoplasmic and very punctate (Figs 15 \& 16). A larger proportion of the large luteal cells was stained positively than was that of the small luteal cells, probably reflecting the higher numbers of mitochondria in large luteal cells. The punctate staining in large luteal cells did not extend to the periphery of the cell (Fig. 16), which by electron microscopy was relatively devoid of mitochondria. In some cultures, even at $2 \mathrm{~h}$, it was possible to visualize a three-dimensional network pattern of staining, particularly in the small luteal cells, and shown somewhat inadequately in two dimensions in Fig. 17. The pattern of staining appeared as strands, many of which encircled the nucleus. The concentration of strands was greatest in the perinuclear region, and least near the extreme periphery, possibly because the flattened cells were thicker in the nuclear region, tapering off towards the periphery of the cell. In the peripheral extensions of small luteal cells, single strands were occasionally seen to be aligned in the direction in which the cell was elongated. As observed by electron microscopy (unpublished observations) these areas were generally devoid of mitochondria except for occasional groups of elongated mitochondria, with their long axes aligned parallel. This suggests that the observed strands of fluorescence were probably due not to strands of single mitochondria aligned head-to-tail but rather composed of several mitochondria in cross-section.

\section{Discussion}

The rate limiting enzyme in the conversion of cholesterol into steroids, cytochrome P-450 ${ }_{\text {sce }}$, was immunolocalized in young, mature and regressing bovine corpora lutea and in dispersed luteal cells. Small and large luteal cells of mature cyclic corpora lutea stained intensely for cytochrome $\mathrm{P}-450_{\text {sce }}$ whereas the other cell types did not.

In young and regressing corpora lutea the intensity of immunostaining of luteal cells was considerably less. The immunostaining was stronger in cultured large luteal cells than in cultured small luteal cells, presumably because of the greater concentration of mitochondria in the cytoplasm in the large luteal cells, suggesting that large luteal cells have a greater content of cytochrome P-450 sce per cell.

The proportion of cytoplasm occupied by mitochondria in bovine small luteal cells is similar to that of theca cells but it is almost two-fold greater in large luteal cells than in granulosa cells (Priedkalns \& Weber, 1968b). Since luteal cells are much larger than follicular cells (Priedkalns et al., 1968) and because follicular cells may divide after ovulation (Donaldson \& Hansel, 1965) an increase in the size of mitochondria (Priedkalns \& Weber, 1968a), in the numbers of mitochondria or both must occur during luteal development in the cow. Concurrent with this increase, an

Figs 15-18. Light micrographs of immunofluorescent staining of small (S) and large (L) luteal cells after collagenase dispersion and culture for $24 \mathrm{~h}$. Anti-cytochrome P-450 scc $_{\text {IgG }}$ was used in Figs $15-17$ and non-immune IgG in Fig. 18. Staining for cytochrome P-450 scc was localized to the cytoplasm of small and large luteal cells and in some preparations it appeared as strands (arrows). Bars $=50 \mu \mathrm{m}$. 
increase in the intensity of staining for cytochrome P-450 $0_{\mathrm{scc}}$ was observed. The intensity of staining was low in granulosa and theca cells (Rodgers et al., 1986b) and corpora lutea of Stage I, when compared with intensity of staining of mature corpora lutea of Stages II and III, in which small and large luteal cells stained positively. In culture, when luteal cells had become flattened, the intensity of staining was observed to be less in small luteal cells than in large luteal cells, which have a higher proportion of their cytoplasm occupied by mitochondria than do small luteal cells. Hence, the intensity of staining of cytochrome $\mathrm{P}-450_{\mathrm{scc}}$ would appear, in part, to be related to the proportion of cytoplasm occupied by mitochondria. In other experiments it was shown that the specific content of cytochrome P-450 scc per $\mu \mathrm{g}$ tissue protein was 12 -fold greater in mature corpora lutea of Stage II than in young corpora lutea of Stage I, whereas that of inner-mitochondrial 'house-keeping' enzymes was only 3-fold greater (Rodgers et al., 1986a). The increase in staining intensity for cytochrome P-450 $0_{\text {sce }}$ from Stage I to Stage II of luteal development may therefore not only have been a function of the proportion of cytoplasm occupied by mitochondria but may also have been a function of the specific content of cytochrome P-450 $\mathbf{s c c}$ in the mitochondria. However, further experiments are necessary to clarify this possibility.

The steroidogenic functions of small and large luteal cells have now been studied in vitro for a number of species, including cattle (Ursely \& Leymarie, 1979a, b; Koos \& Hansel, 1981; Ursely et al., 1981; Chegini et al., 1984), sheep (Fitz et al., 1982, 1984; Rodgers \& O'Shea, 1982; Rodgers et al., 1983, 1985; Hoyer et al., 1984) and pigs (Lemon \& Loir, 1977; Lemon \& Mauleon, 1982). A general consensus has arisen that the small and large luteal cells are steroidogenic and that large luteal cells have a greater capacity (per cell) to produce progesterone in vitro. This is in agreement with the observations here that both small and large luteal cells stained positively for cytochrome $\mathrm{P}-450_{\text {sce }}$, a key enzyme in the biosynthetic pathway to progesterone. Moreover, in cultured cells, it was apparent that the immunostaining for cytochrome $\mathrm{P}-450_{\mathrm{scc}}$ was greater in large luteal cells than in small luteal cells, probably reflecting the greater proportion of cytoplasm occupied by mitochondria in these cells. This suggests that large luteal cells have a greater capacity to produce progesterone, not only on a per cell basis, but also on a per unit volume of cell basis. This is not to say that large cells do in fact produce more progesterone per cell since the production of progesterone is also dependent upon other factors such as the delivery of substrate to the steroidogenic pathway or the degree of stimulation by trophic hormones. Indeed, it would appear from in-vitro studies that the production of progesterone by small luteal cells is more responsive (fold increase above basal) to stimulation by LH than that of large luteal cells, and it may be that progesterone production by large luteal cells is unresponsive to LH (Rodgers et al., 1983) or to cAMP (Hoyer et al., 1984).

The ultrastructure of bovine small and large luteal cells in tissue Priedkalms \& Weber, 1968a, b; Fields et al., 1985) and in dispersed-cell preparations (Koos \& Hansel, 1981; Chegini et al., 1984) has been described previously and much of it has been confirmed in the present manuscript. However, the presence of areas of close abutment with associated adherens-type junctions between the small luteal cells has not been reported. These areas were plentiful and were characterized by parallel segments of apposing membranes separated by a gap of up to $10 \mathrm{~nm}$. In some cross-sections the membranes were connected by regularly spaced cylindrical septa, and as such, these areas fit the description of septate-like junctions or contacts (Friend \& Gilula, 1972). Small areas of adherens-type junctions were found occasionally at one or both ends of these contacts. The functions of septate-like junctions or contacts are poorly understood but suggested functions include the regulation of movement of extracellular fluid between cells (Wood, 1951; Friend \& Gilula, 1972; Bennett \& Goodenough, 1978). In other areas of the small luteal cells the membrane was often folded although not always interdigitating with a neighbouring cell and it is likely that the junctions and not the interdigitations may be the reason for bovine small luteal cells remaining in clumps after enzymic dispersion.

It is concluded that the small and large luteal cells of cyclic bovine corpora lutea contain cytochrome $\mathrm{P}-450_{\text {sce }}$, and at highest concentration when the corpora lutea are fully formed. The concentrations per cell and per unit volume of cell appeared to be greater in the large than in the 
small luteal cells, reflecting the greater numbers of mitochondria, per cell and per unit volume of cell, in large luteal cells.

We thank Dr J. M. Snyder for the provision of histological facilities; Ms S. Hollingsworth for typing this manuscript; the National Institutes of Health for financial assistance (Grants HD-13234, AM-28350, HD-11149); and the Chilton Foundation for a grant-in-aid to R.J.R.

\section{References}

Alila, H.W. \& Hansel, W. (1984) Origin of different cell types in the bovine corpus luteum as characterized by specific monoclonal antibodies. Biol. Reprod. 31, $17015-17025$.

Archbald, L.F., Al-Bagdadi, F. \& Godke, R.A. (1981) A light microscopic and electron microscopic study of the periparturient bovine corpus luteum. Theriogenology 16, 27-38.

Bennett, M.V.L. \& Goodenough, D.A. (1978) Gap junctions, electronic coupling, and intercellular communications. Neurosci. Res. Prog. Bull. 16, 373-486.

Chegini, N., Ramani, N. \& Rao, Ch.V. (1984) Morphological and biochemical characterization of small and large bovine luteal cells during pregnancy. Molec. cell. Endocr. 37, 89-102.

Donaldson, L. \& Hansel, W. (1965) Histological study of bovine corpora lutea. J. Dairy Sci. 48, 905-909.

DuBois, R.N., Simpson, E.R., Tuckey, J., Lambeth, J.D. \& Waterman, M.R. (1981) Evidence for a higher molecular weight precursor of cholesterol sidechain-cleavage cytochrome P-450 and induction of mitochondrial and cytosolic proteins by corticotropin in adult bovine adrenal cells. Proc. natn. Acad. Sci. U.S.A. 78, 1028-1032.

Fields, M.J., Dußois, W. \& Fields, P.A. (1985) Dynamic features of luteal secretory granules: ultrastructural changes during the course of pregnancy in the cow. Endocrinology 117, 1675-1682.

Fitz, T.A., Mayan, M.H., Sawyer, H.R. \& Niswender, G.D. (1982) Characterization of two cell types in the ovine corpus luteum. Biol. Reprod. 27, 703-711.

Fitz, T.A., Mock, E.J., Mayan, M.H. \& Niswender, G.D. (1984) Interactions of prostaglandins with subpopulations of ovine luteal cells. II Inhibitory effects of $\mathrm{PGF}_{2 \alpha}$ and protection by $\mathrm{PGE}_{2}$. Prostaglandins 28, $127-138$.

Friend, D.S. \& Gilula, N.B. (1972) A distinctive cell contact in the rat adrenal cortex. J. Cell Biol. 53, $148-163$.

Gilula, N.B. (1978) Structure of intercellular junctions. In Intercellular Junctions and Synapses, pp. 3-22. Eds, J. Feldman, N. B. Gilula \& J. D. Pitts. Chapman and Hall, London.

Gobel, S. (1971) Axo-axonic septate junctions in the basket formations of the cat cerebellar cortex. J. Cell Biol. 511, 328-333.

Hoyer, P.B., Fitz, T.A. \& Niswender, G.D. (1984) Hormone-independent activation of adenylate cyclase in large steroidogenic ovine luteal cells does not result in increased progesterone secretion. Endocrinology 114, 604-608.

Ireland, J.J., Murphee, R.L. \& Coulson, P.B. (1980) Accuracy of predicting stages of bovine estrous cycle by gross appearance of the corpus luteum. J. Dairy Sci. 63, 155-160.

Koos, R.D. \& Hansel, W. (1981) The large and small cells of the bovine corpus luteum: ultrastructural and functional differences. In Dynamics of Ovarian Function, pp. 197-203. Eds, N. B. Schwartz \& M. Hunzicker-Dunn. Raven Press, New York.

Lemon, M. \& Loir, M. (1977) Steroid release in vitro by two luteal cell types in the corpus luteum of the pregnant sow. J. Endocr. 72, 351-359.

Lemon, M. \& Mauleon, P. (1982) Interactions between two luteal cells types from the corpus luteum of the sow in progesterone synthesis in vitro. J. Reprod. Fert. 64, 315-323.

Parry, D.M., Willcox, D.L. \& Thorburn, G.D. (1980) Ultrastructural and cytochemical study of the bovine corpus luteum. J. Reprod. Fert. 60, 349-357.

Priedkalns, J. \& Weber, A.F. (1968a) Ultrastructural studies of the bovine Graafian follicle and corpus luteum. Z. Zellforsch. mikrosk. Anat. 91, 554-573.

Priedkalns, J. \& Weber, A.F. (1968b) Quantitative ultrastructural analysis of the follicular and luteal cells of the bovine ovary. Z. Zellforsch. mikrosk. Anat. 91, 574-585.

Priedkalns, J., Weber, A.F. \& Zemjanis, R. (1968) Qualitative and quantitative morphological studies of the cells of the membrana granulosa, theca interna and corpus luteum of the bovine ovary. Z. Zellforsch. mikrosk. Anat. 85, 501-520.

Rodgers, R.J. \& O'Shea, J.D. (1982) Purification, morphology, and progesterone production and content of three cell types isolated from the corpus luteum of the sheep. Aust. J. biol. Sci. 35, 441-455.

Rodgers, R.J., O'Shea, J.D. \& Findlay, J.K. (1983) Progesterone production in vitro by small and large ovine luteal cells. J. Reprod. Fert. 69, 113-124.

Rodgers, R.J., O'Shea, J.D. \& Findlay, J.K. (1985) Do small and large luteal cells of the sheep interact in the production of progesterone? J. Reprod. Fert. 75, 85-94.

Rodgers, R.J., Waterman, M.R. \& Simpson, E.R. (1986a) Cytochromes P-450 ${ }_{\text {scc }}$, and P-450 $17 a$, adrenodoxin and reduced nicotinamide adenine dinucleotide phosphate-cytochrome $\mathrm{P}-450_{\text {scc }}$ reductase in bovine follicles and corpora lutea. Changes in specific contents during the ovarian cycle. Endocrinology 118, 1366-1374.

Rodgers, R.J., Rodgers, H.F., Hall, P.F., Waterman, M.R. \& Simpson, E.R. (1986b) Immunolocalization of cholesterol side-chain-cleavage cytochrome P-450 and $17 \alpha$-hydroxylase cytochrome P-450 in bovine ovarian follicles. J. Reprod. Fert. 78, 627-638.

Seybert, D.W., Lancaster, J.R., Jr, Lambeth, J.D. \& 
Kamin, H. (1979) Participation of the membrane in the side-chain-cleavage of cholesterol. Reconstitution of cytochrome $\mathrm{P}-450_{\mathrm{scc}}$ into phospholipid vesicles. $J$. biol. Chem. 254, 12088-12098.

Ursely, J. \& Leymarie, P. (1979a) Varying response to luteinizing hormone of two luteal cell types isolated from bovine corpus luteum. J. Endocr. 83, 303-310.

Ursely, J. \& Leymarie, P. (1979b) A comparison of the LH control of progesterone synthesis in small and large cells from pregnant cow corpus luteum. In Ovarian Follicular and Corpus Luteum Function, pp. 545-548. Eds, C. P. Channing, J. M. Marsh \& W. A. Sadler. Plenum Press, New York.
Ursely, J., Darbon, J-M. \& Leymarie, P. (1981) Aromatization of testosterone in large and small bovine luteal cells. Conflicting results between radioimmunoassay and co-crystallization data. Steroids 38, 271-279.

Wood, R.L. (1959) Intercellular attachment in the epithelium of Hydra as revealed by electron microscopy. J. Biophys. Biochem. Cytol. 6, 343-363.

Received 2 April 1986 